\title{
Verbalization of the concept People in Politics with the help of phraseological units of the English language
}

\author{
Yu. Shtoltsel \\ Uzhhorod National University, Uzhhorod, Ukraine \\ Corresponding author. E-mail: yuliannahotra2016@gmail.com \\ Paper received 18.06.18; Accepted for publication 25.06.18.
}

https://doi.org/10.31174/SEND-Ph2018-176VI51-16

\begin{abstract}
The given article focuses on the verbalization of the concept People in Politics with the help of phraseological units in the modern English press. Having analyzed the most serious readable British and American newspapers, the author has found 13 examples of phraseological units characterizing concept People in Politics which were divided into 3 frames: a Political minority, a Political majority, People in Politics. According to the results of the analysis, we can conclude that idioms are common in political discourse as they make the language of the press richer and emotionally coloured. We analyzed the concept, frame and phraseological unit definitions. We selected the phraseological units from the newspapers to refer to the concept of People in Politics within the English-language newspaper discourse. Also, we showed the negative and positive connotation of the idioms. Further prospects we see in the study of the idioms within the socio-political vocabulary.

Keywords: phraseology, concept, verbalization of the concept, frame.
\end{abstract}

Formulation of the problem. The language of every nation seeks to reflect and characterize any phenomena of human life, its features of character, appearance, abilities, physical and emotional states, etc., appealing to the cultural traditions that have developed in society, scientific, philosophical, religious views, moral guidelines, and also to the experience of everyday life. Phraseology appears as the area of speech in which the most vivid representation of a person and the world around is most clearly reflected.

The main focus of the article is on the analysis of phraseological units that are found in contemporary Englishlanguage newspapers, namely articles on politics and political speeches. The choice of research material is not accidental, it is because the modern press keeps the cultural identity of the nation in the language, indicating the development of the linguistic picture of the world. It determines the relevance of our research.

This topic also points to the need to expand and substantially deepen knowledge about the linguistic representation of the linguistic-cultural concept People in Politics in building a model of English mentality that helps to identify ways of interaction between the verbal and cultural codes of a nation.

The purpose of the study is to identify ways of verbalizing the concept People in Politics with the use of phraseological units as mental entities on the basis of the material of the English-language newspaper discourse.

The given purpose of the scientific work involves solving the following tasks:

- to define the concept of "phraseological unit";

- to convey the meaning of the concept and means of its verbalization;

- explode phraseological units to refer to the concept of People in Politics within the English-language newspaper discourse;

- to show negative and positive connotation of the given idioms.

The object of research is the concept People in Politics in the 21st Century English Press.

The subject of the work is the phraseological units to designate the concept of People in Politics in the Englishlanguage picture of the world.
The material of the study is the phraseology of the English language, obtained through a continuous selection of modern British press. For search, materials from the online editions of The Guardian, Bloomberg, Forbes, Daily Mirror, The Washington Post, The Atlantic, and others during the period of May 2018 were used. About fifty idioms were analyzed, of which, for our article, thirteen were selected for the concept of People in Politics.

The organization of the study stages of the linguisticcultural concept "People in Politics" involves the use of a comprehensive methodology:

- continuous sampling method;

- method of phraseological identification

- definition and component analysis

- the procedure of quantitative calculations and others.

Presenting the main material.

In languages, there are many phrases that are commonly referred to as phraseological units or idioms. Such lexical units make our language expressive. Most of them are based on vivid metaphors, comparisons, and juxtapositions. Many idioms carry the image; they reflect human wisdom and wit. In the Ukrainian and Russian linguistic tradition, they are called phraseological units. British and American linguists prefer the term idioms.

The phraseological unit is an unmotivated word group that cannot be freely formulated in the language but is reproduced as a ready unit $[1$, p. 3].

As for the concept, O. Kubryakova advocates the idea that "the concept is a term used to explain the units of the mental or psychic resources of consciousness and the information structure that reflects the knowledge and experience of man; it is the operational content unit of memory, the mental lexicon, the conceptual system and the language of the brain, the whole picture of the world, reflected in the human psyche. The concept arises when constructing information about objects and their properties, and this information can include both information about the objective state of affairs in the world, as well as information about the imaginary worlds and the possible state of affairs in these worlds. This is the information that the individual knows, assumes, thinks and imagines about the objects of the world "[3, p. 90-92]. 
According to the O. Selivanova interpretation, the concept is an information structure of consciousness, a differently subjective, somehow organized unit of memory, which contains a set of knowledge about the object of knowledge, verbal and nonverbal, acquired through the interaction of the five mental functions of consciousness and the unconscious [ 4, p. 256].

With the help of contemporary English dictionaries (Longman dictionary of contemporary English, Cambridge dictionary, Oxford dictionary, etc.), we isolate the following frames (semantic frames) in the concept of people in politics using the keywords found in their meaning:

1. Political minority

2. Political majority

3. Politician (leader, candidate, a local body of government)

We should note that the frame is a model of cultural knowledge, which is common to at least part of society [2]. It is necessary also to point out that the above semantic frameworks are undoubtedly interrelated, that is, they are those that interact with each other. In addition, it should be indicated that this concept and its frames are verbalized in our study solely with the help of phraseological units. The lexemes minority, majority and politician have the following meanings in the dictionaries:

- Longman dictionary of contemporary English: Minority (noun) [singular] a small group of people or things within a much larger group;

The Majority (noun) [singular] most of the people or things in a group.

- Cambridge dictionary: Minority [ C ] any small group in society that is different from the rest because of their race, religion, or political beliefs, or a person who belongs to such a group.

The Majority [ C ] in an election, the difference in the number of votes between the winning person or group and the one that comes second

- Oxford dictionary: Minority (noun) A small group of people within a community or country, differing from the main population in race, religion, language, or political persuasion

Majority British (noun) The number by which the votes cast for one party or candidate exceed those for the next.

US (noun) The number by which votes for one candidate are more than those for all other candidates together.

- Cambridge dictionary: Politician (noun) 1. a member of a government or law-making organization; 2. a person who is active in politics, esp. as a job

- Collins Dictionary: 1. a person actively engaged in politics, esp. a full-time professional member of a deliberative assembly; 2 . a person who is experienced or skilled in the art or science of politics, government, or administration; statesman; 3. (derogatory, mainly US) a person who engages in politics out of a wish for personal gain, as realized by holding a public office

I. Therefore, the "Political minority" frame is distinguished by the following keywords found in the meanings of phraseology: members, children without legal permission, downtrodden. For example:

Anchor Babies - A derogatory term for children born in the United States of parents who are in the country without proper authorization or who may have arrived into the nation across the US/Mexico border without legal permission. Current US law provides US Citizenship to any baby born on US Soil. Those babies are afforded rights and benefits of all US Citizens that some say their parents then use to provide an anchor or basis to remain in the United States indefinitely. The term is used widely by opponents of illegal immigration especially among those in border states.

The myth of the 'anchor baby' deportation defence. (The Washington Post, August 20, 2015)

Teabaggers - a derogatory term to reference members of the Tea Party movement. T.e.a. stands for Taxed Enough Already.

Obama Calls Tea Partiers 'Tea-Baggers'. (The Atlantic, May 4, 2010)

Bleeding Heart: A term describing people whose hearts "bleed" with sympathy for the downtrodden; used to criticize liberals who favour government spending for social programs

Their subtitle, "The Bleeding-Heart Conservative Who Changed America," riffs off of one of Kemp's favourite self-descriptions. (The Atlantic, October 12, 2015)

II. The frame "Political majority" has the following keywords in its structure: a mass of Americans, a portion of the electorate, a group of people, a wealthy person. For instance:

Silent Majority: The mass of Americans whose opinions are not loud and public, but who together have enormous power. Popularized by President Richard Nixon, who claimed that Vietnam War protesters comprised a minority, while a "silent majority" supported the war.

Catalan leader faces a dilemma as silent majority finds its voice. (The Guardian, October 8, 2017)

Swing Vote: The undecided, usually independent, portion of the electorate that can "swing" the outcome of an election one way or the other

A Surge in migrant voters could swing vote in key UK constituencies. (The Guardian, January 29, 2015)

The Body politic: A group of people organised under a single government or authority (national or regional) is a body politic.

Champagne socialist: (UK) A wealthy person who has left-wing views is a champagne socialist, especially if political beliefs are seen as shallow or hypocritical.

From latte socialist to gauche caviar - how to spot good-time leftwingers around the world. (The Guardian 23.11.2017)

III. The frame "Politician" has the following keywords in its structure: organization, politicians, leader, candidate. For example:

Bully Pulpit: The Presidency, when used by the President to inspire or moralize. Whenever the President seeks to rouse the American people, he is said to be speaking from the bully pulpit. When the term first came into use, "bully" was slang for "first rate" or "admirable."

Five Ways Leaders Can Use The Bully Pulpit To Be More Effective Communicators. (Forbes, January 19, 2017)

Coattails effect: The power of a popular candidate to gather support for other candidates in his or her party. Winning candidates are said to have coattails when they 
drag candidates for lower office along with them to victory.

A Closer Look at Trump's 'Coattails Effect'. (Bloomberg, November 17, 2016)

Dark Horse: A long-shot candidate.

Three dark horse candidates to watch in California's U.S. Senate race. (LA Times, June 3, 2018)

Demagogue leader: A leader whose impassioned rhetoric appeals to greed, fear, and hatred, and who often spreads lies. Former U.S. Sen. Joseph McCarthy (see McCarthyism) is often cited as a classic demagogue.

What History Teaches Us About Demagogues Like The Donald. (Bloomberg June 20, 2016)

Fence Mending: What politicians do when they visit their electoral districts to explain an unpopular action. The term originated in 1879 when Ohio Senator John Sherman made a trip home that most people considered a political visit. Sherman insisted, however, that he was home "only to repair my fences."

T-Mobile CEO Checks Into Trump Hotel on FenceMending D.C. Mission. (Bloomberg 3 May 2018)

Machine Politics: Politics controlled by a tightly-run organization that stresses discipline and rewards its supporters. Machines are usually found in large cities and are frequently accused of corruption.
The age of machine politics is over. But still, it thrives in the Labour party. (The Guardian, 4 Jun 2015)

According to the results of the analysis, we can conclude that phraseological units are often used in political discourse as they make the language of the press richer and emotionally coloured. Consequently, we chose from the newspapers idioms to refer to the concept of People in Politics within the English-language newspaper discourse. With the help of modern dictionaries of English phraseology, we are assured that all selected linguistic units belong to phraseological units. Based on this, we divided the concept into three frames: the Political majority, the Political minority and Politician, which in this study are verbalized solely with phraseological units. We must also point out that 8 idioms from 13 have negative connotations (anchor babies, teabaggers, bleeding heart, champagne socialist, dark horse, demagogue leader, fence mending and machine politics), with regard to the other 5 idioms, they are related to the positive connotations (silent majority, swing vote, body politic, bully pulpit and coattail effect).

Prospects we see in the further study of the idioms within the socio-political vocabulary.

\section{REFERENCES}

1. Valueva I.V. Comparative study of phraseological units with a loose mic component of paradigm and syntagmatic (based on the material of the English texts of the twentieth century): author's abstract. dis for obtaining a scientific degree of philological sciences candidate: 10.02.04 / I.V. Valueva. - Odessa State University - O., 1996. - 15 p.

2. Dike T.A. Frames of Knowledge and Understanding of Voice Acts // Language. Cognition. Communication / T.A. Dike M.: Progress, 1989. - December 12-14.

3. Kubryakova E. A Short dictionary of cognitive terms / E.A. Kubryakova - M.: Philological faculty

Moscow State University named after M.V. Lomonosov, 1996. $245 \mathrm{p}$.

4. Selivanova O. Modern Linguistics: Terminological Encyclopedia. / O. Selivanova. - Poltava: Environment, 2006. $-716 \mathrm{p}$. 